This paper has to be cited as: Tomás, R., García-Barba, J., Cano, M., Sanabria, M.P., Ivorra, S., Duro, J. \& Herrera, G. 2012. Subsidence damage assessment of a gothic church using Differential Interferometry and field data. Structural Health Monitoring, 11, 751-762. The final publication is available at SAGE journals via: http://shm.sagepub.com/content/11/6/751.abstract

\title{
Subsidence damage assessment of a gothic church using Differential Interferometry and field data
}

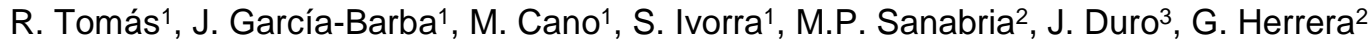

(1) Departamento de Ingeniería de la Construcción, Obras Públicas e Infraestructuras Urbanas. Escuela Politécnica Superior, Universidad de Alicante, P.O. Box 99, E-03080 Alicante, Spain.E-mail: roberto.tomas@ua.es

(2) Instituto Geológico y Minero de España, Ríos Rosas 23, E-28003 Madrid, Spain. Email:g.herrera@igme.es

(3) Altamira Information, c/ Còrsega, 381-387, 2n 3a - E-08037 Barcelona, Spain. E-mail: javier.duro@altamira-information.com

\section{Abstract}

The Santas Justa and Rufina gothic church (XIV century) has suffered several physical, mechanical, chemical and biochemical types of pathologies along its history: rock alveolization, efflorencescences, biologic activity and capillary ascent of ground water. However, during last two decades a new phenomenon has seriously affected the church, the ground subsidence caused by aquifer overexploitation. Subsidence is a process that affects the whole Vega Baja of the Segura River basin and consists on the gradual sinking of ground surface caused by soil consolidation due to a pore pressure decrease. This phenomenon has been studied by means of Differential SAR Interferometry (DInSAR) techniques providing settlements up to $100 \mathrm{~mm}$ for the 1993-2009 period for the whole Orihuela city. Although no DInSAR information is available for the church due to the loss of interferometric coherence, a spatial analysis of the deformations affecting the neighbour areas jointly to field reported information has allowed to better understand the mechanisms that affect the Santas Justa and Rufina church, showing the potential interest of these remote sensing techniques for supporting building forensic analyses.

Keywords: Forensic analysis, DInSAR, ground subsidence, gothic church, historic building monitoring

Research highlights: Santas Justa and Rufina has suffered several kinds of pathologies along its history > The last two decades the church has been affected by ground subsidence processes due to aquifer overexploitation > Subsidence has seriously affected the church $>$ The joint use of DInSAR techniques and field observations has permitted to better understand subsidence pathologic processes affecting the church 
This paper has to be cited as: Tomás, R., García-Barba, J., Cano, M., Sanabria, M.P., Ivorra, S., Duro, J. \& Herrera, G. 2012. Subsidence damage assessment of a gothic church using Differential Interferometry and field data. Structural Health Monitoring, 11, 751-762. The final publication is available at SAGE journals via: http://shm.sagepub.com/content/11/6/751.abstract

\section{Introduction}

Subsidence due to water level withdrawal is a well-known phenomenon that implies the ground settlement due to an increase in soil effective stresses caused by piezometric level decrease. This phenomenon is not spatially uniform due to changes in soil properties and spatial variation of deformable soil thickness and piezometric levels, causing differential settlements and distortions affecting buildings founded on ground surface. The measurement of evolution and distribution of these settlements is necessary in order to adopt the appropriate actions to be corrected or minimised. During last years, Differential SAR interferometry (DInSAR) has become a very useful tool for subsidence study. This technique has been specifically useful for study urban areas as México city (Osmanoğlu et al., 2010), Rome (Stramondo et al., 2008), Lisbon (Heleno et al., 2011), París (Fruneau et al., 2005) among others. Furthermore, a more specific monitoring of structures affected by ground subsidence has been performed by Herrera et al. (2010) and Bru et al. (2010) in the city of Murcia (Spain) affected by subsidence, allowing to successfully understand deformational behavior of some structures. In this work, a forensic analysis of the Santas Justa and Rufina church (Figures 1 and 2), located in Orihuela (Alicante province, Spain, Figure 3) using DInSAR is performed jointly with in situ observations data. The Santas Justa and Rufina church was built in the Gothic style in the XIV century and was declared a Spanish National Monument in 1971. Throughout its history, the structure has been repaired several times after suffering the results of seismic movements, fires, etc. In the last two decades, a new phenomenon has appeared that could affect the building's structural integrity. A series of long-term droughts in South-East Spain jointly with the aquifer overexploitation has caused a high piezometric level descent that has increased the soil effective stresses causing a consolidation process that is manifested on ground surface as settlements. These settlements have affected the Santas Justa and Rufina church causing several damages. The field data, mainly geotechnical data and in situ observations, jointly with DInSAR data has allowed to diagnose the problems affecting the church.

The paper is organized as follows. Section 2 describes Santas Justa and Rufina church principal structure characteristics. Available information and previous works conducted in the church are briefly described in Section 3 . Section 4 is devoted to define the geological and geotechnical setting of the study area. Section 5 includes an explanation of damages observed during field works in the church and section 6 is dedicated to subsidence measurements obtained using DInSAR. Then, a diagnosis is performed in section 7 using all previously described information. Finally, section 8 presents the main conclusions.

\section{Description of the gothic church}

The Santas Justa and Rufina church, declared a Spanish National Monument in 1971, is located in Orihuela (Alicante province, Spain)(Figure 1). It is a Catholic church built in the XIV century and reformed in the XVI and XVIII centuries, presenting both Gothic and Baroque 
This paper has to be cited as: Tomás, R., García-Barba, J., Cano, M., Sanabria, M.P., Ivorra, S., Duro, J. \& Herrera, G. 2012. Subsidence damage assessment of a gothic church using Differential Interferometry and field data. Structural Health Monitoring, 11, 751-762. The final publication is available at SAGE journals via: http://shm.sagepub.com/content/11/6/751.abstract

influences. It consists of a main body with lateral chapels located between the counterforts (Figures $1 \mathrm{~b}$ and 2). Among all lateral chapels there are two higher chapels, San José chapel, located at the NW of the church, and La Comunión chapel, placed at the SW. There are two doors, the main located at the west façade (Figures 1a and 2), and a lateral door (Evangelio door) placed at north façade (Figures $1 c$ and 2). The sacristy, with a square plant, and the antesacristy, with a rectangular plant, are sited at the SE part of the church. Finally, the bell tower found at the north of the church reaches a height of $35.5 \mathrm{~m}$ (Figure 1a). The entire building is built of masonry with bricks and ashlars and is directly founded over silts and clays overlaying the church that will be described in detail on section 4 .

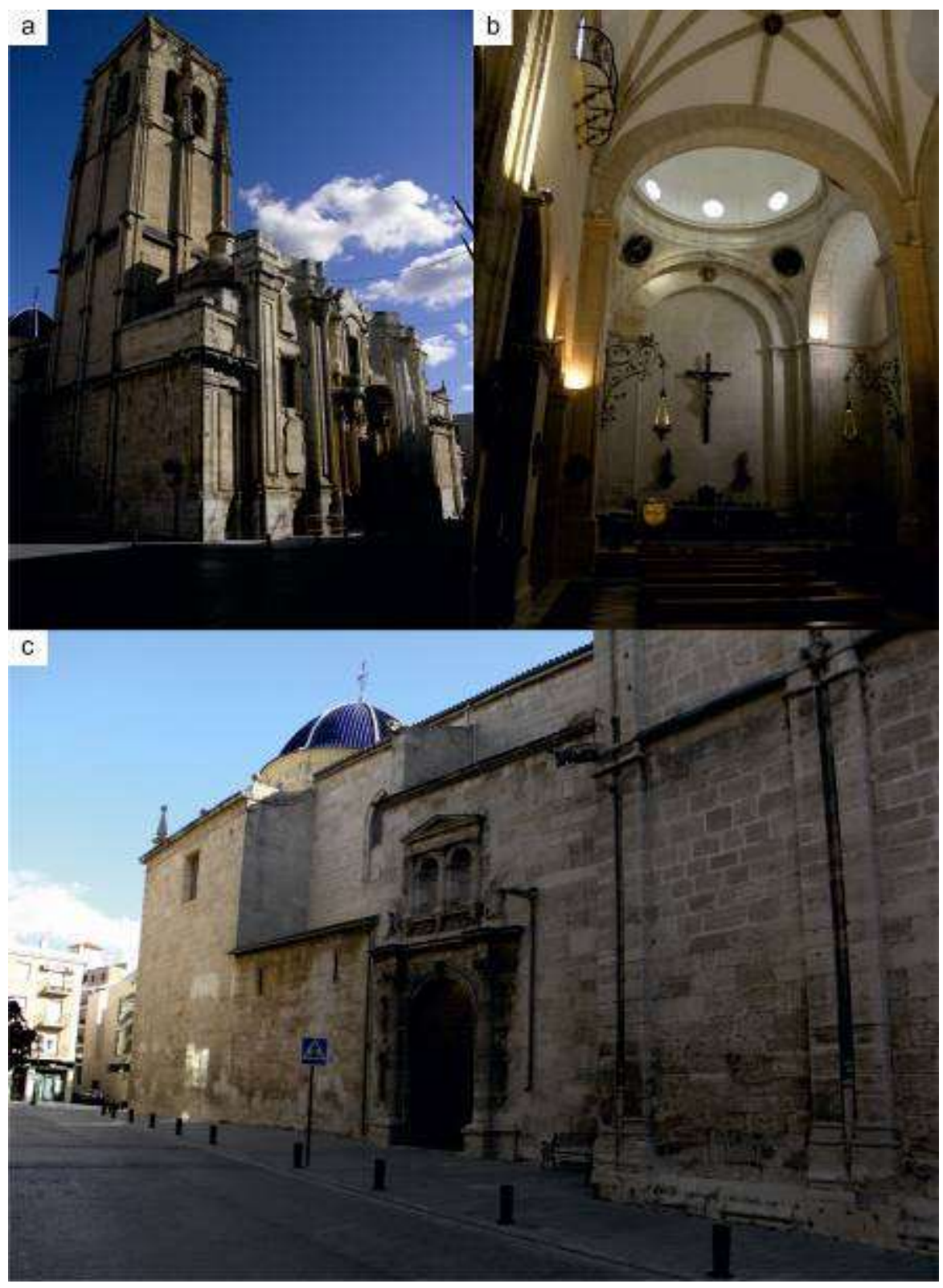


This paper has to be cited as: Tomás, R., García-Barba, J., Cano, M., Sanabria, M.P., Ivorra, S., Duro, J. \& Herrera, G. 2012. Subsidence damage assessment of a gothic church using Differential Interferometry and field data. Structural Health Monitoring, 11, 751-762. The final publication is available at SAGE journals via: http://shm.sagepub.com/content/11/6/751.abstract

Figure 1. Photograph of the Santas Justa and Rufina church: (a) North-west corner. Notice the main door and the bell tower. (b) Main body. Observe the main chapel. (c) North façade with the Evangelio door. See location of these elements on Figure 2.
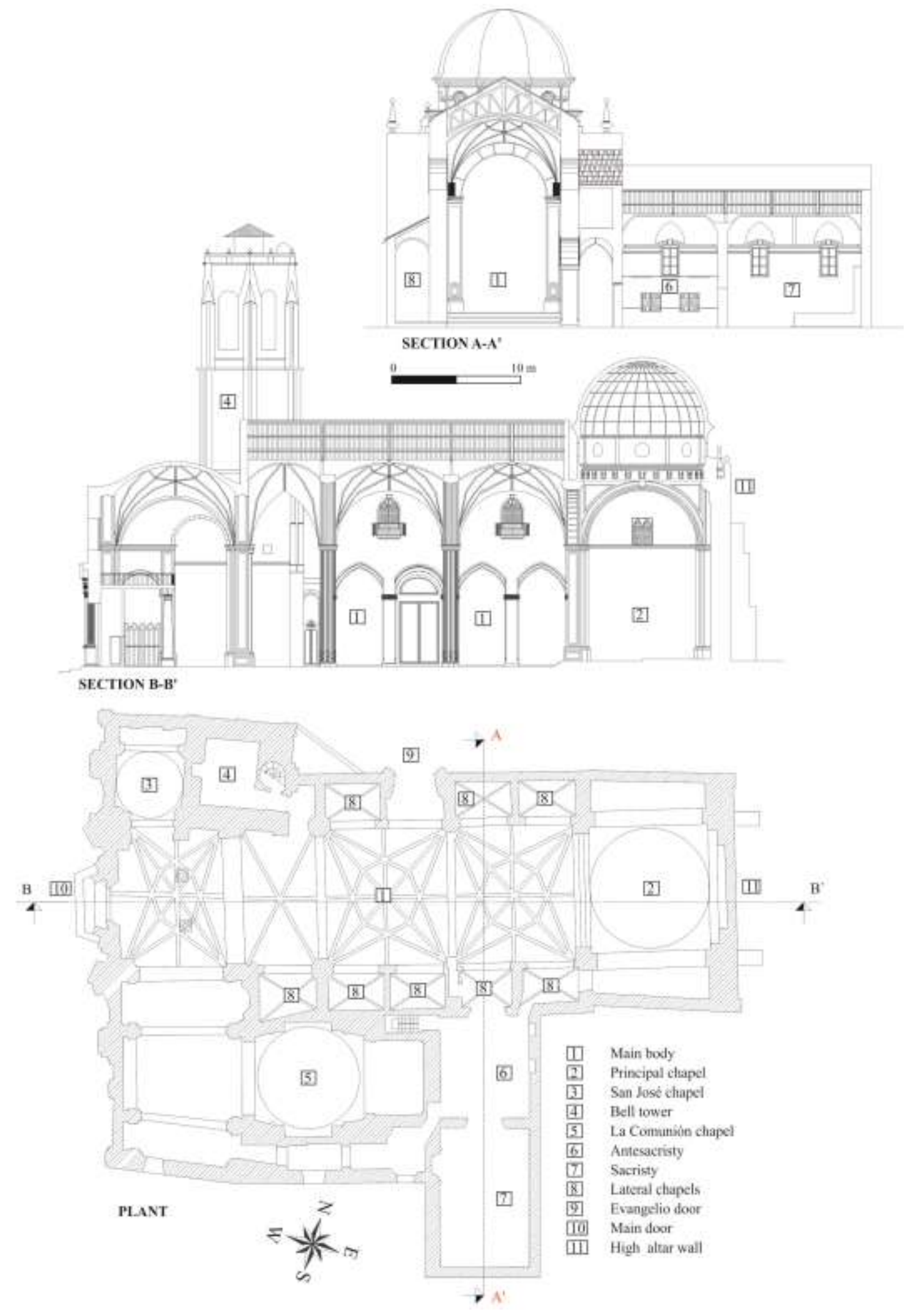

Figure 2. Cross sections and plant of the Santas Justa and Rufina church. 
This paper has to be cited as: Tomás, R., García-Barba, J., Cano, M., Sanabria, M.P., Ivorra, S., Duro, J. \& Herrera, G. 2012. Subsidence damage assessment of a gothic church using Differential Interferometry and field data. Structural Health Monitoring, 11, 751-762. The final publication is available at SAGE journals via: http://shm.sagepub.com/content/11/6/751.abstract

\section{3. Available information and previous works}

91 The Vega Baja of the Segura River has suffered subsidence processes due to groundwater withdrawal, at least since first years of 90's decade, as showed in several news related with important settlements on the west end of Orihuela city. Moreover, a lot of studies have been performed on this area in order to measure subsidence and its relationship with piezometric levels variation. Tomás et al., (2007) studied subsidence from 1993 to 2001 in the Vega Baja of the Segura River using DInSAR techniques measuring values up to $70 \mathrm{~mm}$ for the Orihuela city and up to $50 \mathrm{~mm}$ for the church neighbourhood. Tomás et al. (2010) contrasted subsidence data for 1993-2009 period obtained by means of DInSAR techniques with subsidence triggering and conditioning factors. Measured settlements for this period were up to $100 \mathrm{~mm}$ for the whole urban area and up to $80 \mathrm{~mm}$ for the Santas Justa and Rufina church vicinity. Ivorra et al., (2010) has studied the incidence of soil subsidence on the dynamic behaviour of a Santa Justa y

102 Rufina bell tower.

103 Historical information of the church is available on parochial archives since the church 104 construction. They include a big amount of data about the church in great detail. However, most of the historical information provided by parochial archives is referred to the modifications and maintenance works performed along the time. Several geotechnical reports of the Orihuela city are available. Three of them are focused on the church under study, although unfortunately only one is available. The available geotechnical report was performed specifically for studying the church pathologies on 2007. This geotechnical report includes three boreholes and useful information about the lithology and the geotechnical properties of soil that are summarized in section 4.

\section{4. Geological and geotechnical characterization}

\section{$114 \quad$ 4.1. Geological setting}

115 The Vega Baja of the Segura River (VBSR) is located in the more oriental sector of the Betic

116 Cordillera. The study area constitutes a monoclinal structure essentially controlled by the strike-

117 slip Crevillente Fault Zone at the $\mathrm{N}$ that represents the convergence of two main structures of 118 the Betic Cordillera: the Cádiz-Alicante Fault System (Sanz de Galdeano, 1990) and the Trans-

119 Alborán Shear Zone (De Larouziére et al., 1988).

120 The Mesozoic basement of the basin consists of carbonate and evaporitic rocks from the Betic 121 External Zones protrude at the $\mathrm{N}$ and $\mathrm{E}$ area of the study zone (Delgado et al, 2002). The Bajo 122 Segura Basin is filled by Neogene-Quaternary sediments (Figure 3).

123 The valley filling is composed on Holocene sediments at the ground surface beyond Pleistocene 124 sediments deposited by River Segura depositional activity, whereas the eastern zones towards 
This paper has to be cited as: Tomás, R., García-Barba, J., Cano, M., Sanabria, M.P., Ivorra, S., Duro, J. \& Herrera, G. 2012. Subsidence damage assessment of a gothic church using Differential Interferometry and field data. Structural Health Monitoring, 11, 751-762. The final publication is available at SAGE journals via: http://shm.sagepub.com/content/11/6/751.abstract

125 the Mediterranean Sea are occupied by littoral and lagoonal sediments (Delgado et al., 2002).

126 Anthropic deposits can be also found at certain points in the valley generally related with urban

127 areas. Recent sediments are the most compressible ones in the area and the most problematic

128 from a geotechnical point of view.

129 The study area belongs to the so-called "Guadalentín-Segura Quaternary aquifer System No

130 47" (IGME, 1986), an aquifer characterized by two units: a) a surface unconfined aquifer unit

131 with a low conductivity composed by fine sand and silts deposited by the recent activity of the

132 Segura River and coastal processes (towards the $E$ of the zone) whose water table is found a

133 few meters below the ground surface. b) A second unit formed by gravels, usually interbedded

134 with marls that constitutes a confined aquifer with greater hydraulic conductivity than the

135 superficial aquifer (DPA-ITGE, 1996). The upper aquifer is the most scarcely exploited.

136

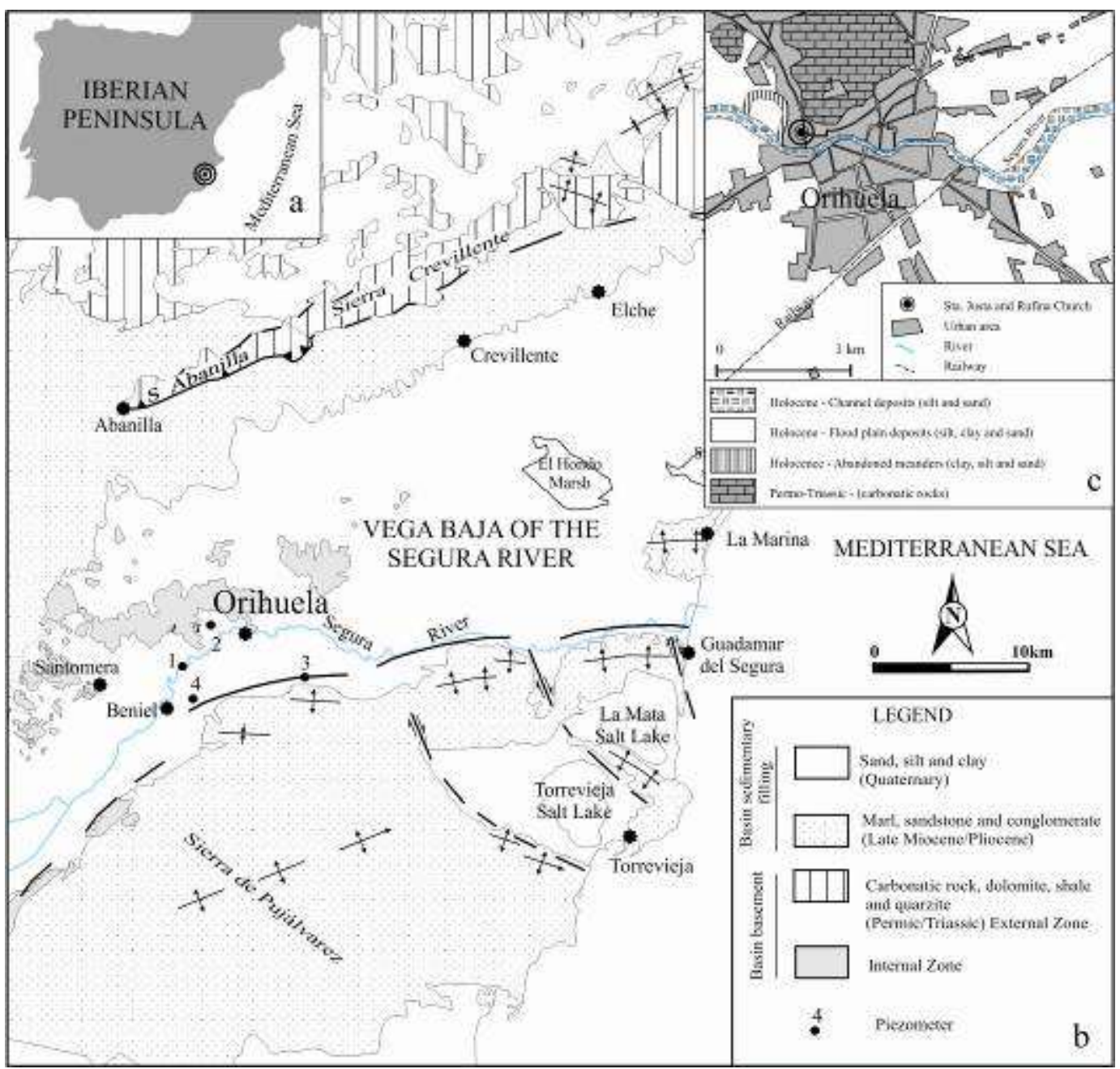

138 Figure 3. Location and geological setting of the city of Orihuela and the Santa Justa and Rufina 139 Church. 
This paper has to be cited as: Tomás, R., García-Barba, J., Cano, M., Sanabria, M.P., Ivorra, S., Duro, J. \& Herrera, G. 2012. Subsidence damage assessment of a gothic church using Differential Interferometry and field data. Structural Health Monitoring, 11, 751-762. The final publication is available at SAGE journals via: http://shm.sagepub.com/content/11/6/751.abstract

\section{$141 \quad$ 4.2. Geotechnical setting}

142 Delgado et al. (2002) made a geological-geotechnical characterization of the Vega Baja of the

143 Segura River basin based o stratigraphic and geotechnical information. This model shows that 144 sedimentary rocks, that constitute the geotechnical substratum, outcrops on the edges of the 145 valley and are also found at certain depths, varying between 0 to $45 \mathrm{~m}$ towards the west, where 146 the town of Orihuela is located. Sediments located above this basement are characterized by 147 moderate to high compressibility, with compression indexes (Cc) varying from 0.07 to 0.29 148 (Delgado et al., 2002; Tomás et al., 2010) and with an average value of 0.18. These sediments 149 are the most compressible ones in the zone and as a consequence the most problematic from a 150 geotechnical point of view.

151

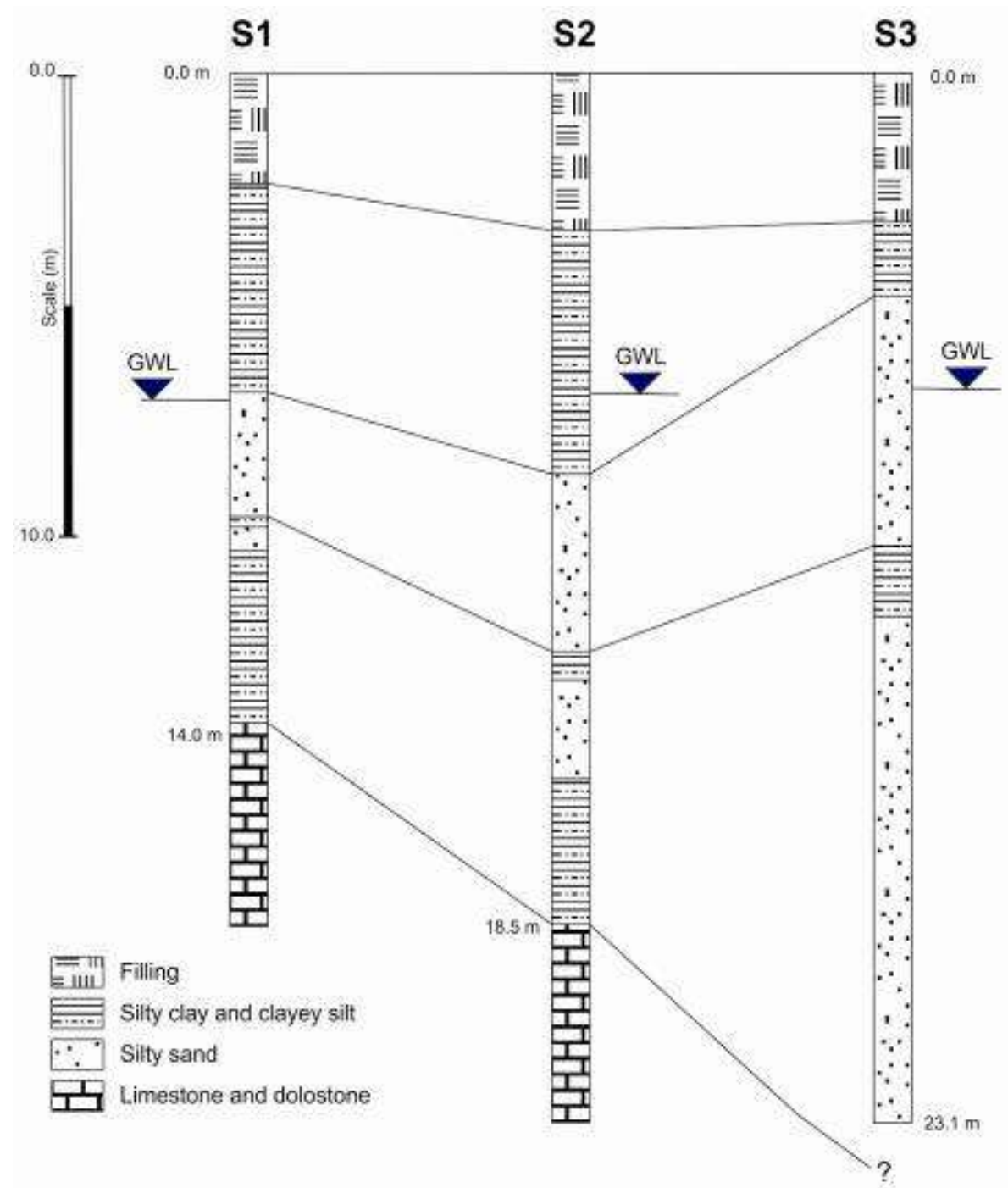

Figure 4. Geotechnical boreholes performed in the Santas Justa and Rufina gothic church. 
This paper has to be cited as: Tomás, R., García-Barba, J., Cano, M., Sanabria, M.P., Ivorra, S., Duro, J. \& Herrera, G. 2012. Subsidence damage assessment of a gothic church using Differential Interferometry and field data. Structural Health Monitoring, 11, 751-762. The final publication is available at SAGE journals via: http://shm.sagepub.com/content/11/6/751.abstract

156 Three geotechnical boreholes have been drilled in the proximities of the church (Figure 4) in 157 order to better know the substrate properties and the geometry under the church. Four different 158 lithologies have been recognized (from top to bottom): a) Fillings; b) Silty clays and clayey silts; 159 c) Silty sand; and d) Limestones and dolostones.

160 The fillings have up to $2 \mathrm{~m}$ depth and present a low relative density with standard penetration 161 test results lower than 5 blow counts. Next layer is composed by silty clays and clayey silts that 162 present a slight improvement of the properties (standard penetration test up to 6 blow counts). 163 The penetration values of this lithology increase notably with depth, reaching maximum values 164 up to 15 blow counts on standard penetration test. Silty sands are intercalated among 165 previously described layer. These sands have a higher penetration resistance than fillings and 166 more surficial silty clays layer (11 blow counts). The geotechnical substrate is constituted by 167 carbonatic rocks (Figure 4), limestones and dolostones with refusal values on standard 168 penetration test and uniaxial compressive strength higher than $30 \mathrm{MPa}$. This layer appears at a 169 depth higher than $16.0 \mathrm{~m}$ and is usually used for founding deep foundations due to the 170 considerable improvement of its geotechnical properties. Notice that the depth of this layer 171 changes in a few meters with slopes higher than $0.19 \mathrm{~m}$ per meter $\left(>11^{\circ}\right)$ in the church area.

\section{5. Damages description}

174 The Santas Justa and Rufina church has suffered several performances and maintenance 175 works along its history. However, this work is focused on the damages that affected the church 176 during last two decades. Although the more serious damages observed last years have been 177 trigged by deformations induced by regional land subsidence, other kinds of damages (Figure 5)

178 have affected the church: (a) Rock alveolization, (b) Efflorencescences, (c) Biologic activity and 179 (d) Capillary ascent of ground water.

180 Rock alveolization is observed in sandstones blocks of several elements of the church causing 181 cluster of small cavities and an evident loss of resistance (Figure $5 \mathrm{~d}$ ). These holes can be the 182 result of the stonework (stacking), biological activity (pits) or the action of salt in the irregular 183 porous network of the marble (alveoli) (Chabas and Jeannette, 2001). The salts form 184 efflorescence growing on rock surface (Figure $5 \mathrm{c}$ and f) composed of small crystals that can 185 influence both weathering and disintegration (alveolization) of the rocks. Microorganisms (fungi, 186 moho, lichens, etc.) and other organisms (birds, plants, etc.) can cause a wide range of 187 pathologies that are out of the scope of this work. Due to the high water level and the proximity 188 to the Segura River, capillarity ascent affects the lower part of the elements that are in contact 189 with soil although humidity can affect higher elements (cupules, columns heads, etc.) when rain 190 access through preexisting cracks (Figure 5f). Salts from ground water can be transported by 
This paper has to be cited as: Tomás, R., García-Barba, J., Cano, M., Sanabria, M.P., Ivorra, S., Duro, J. \& Herrera, G. 2012. Subsidence damage assessment of a gothic church using Differential Interferometry and field data. Structural Health Monitoring, 11, 751-762. The final publication is available at SAGE journals via: http://shm.sagepub.com/content/11/6/751.abstract

191 capillarity through the rock pore system causing salt crystallization, which is the origin of the 192 previously mentioned efflorescence and alveolization processes.

193
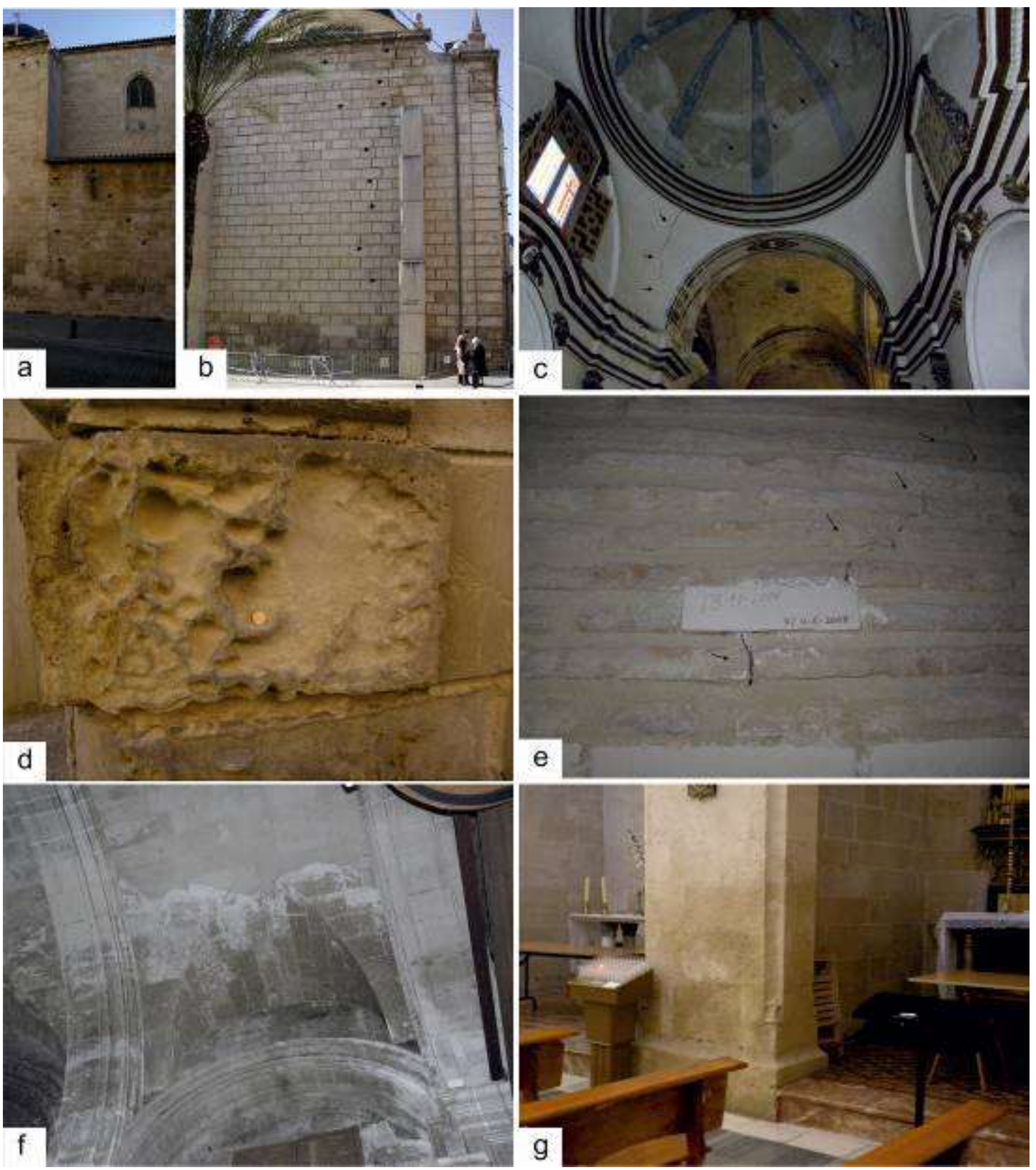

Figure 5. Pathologies observed in the Santas Justa y Rufina church: a) vertical cracks related with a rigidity change; b) cracks due to local effects of counterfort; c) cupola cracks due to differential movements of the base; d) Cluster of small cavities (alveoli); e) masonry cracks induced by differential movements. Notice, the installed plaster markers for crack monitoring f) Efflorescences due to rain infiltration; g) Capillary ascent of water. 
This paper has to be cited as: Tomás, R., García-Barba, J., Cano, M., Sanabria, M.P., Ivorra, S., Duro, J. \& Herrera, G. 2012. Subsidence damage assessment of a gothic church using Differential Interferometry and field data. Structural Health Monitoring, 11, 751-762. The final publication is available at SAGE journals via: http://shm.sagepub.com/content/11/6/751.abstract

Although the above mentioned problems can cause long-term damages, the more dangerous pathologies are affecting structural elements, i.e. walls and columns. Santas Justa and Rufina church is affected by a regional process of subsidence due to water level descend. As is has been previously explained in section 3, accumulated settlements up to $100 \mathrm{~mm}$ have been measured in the Orihuela city from 1993 to 2009. The magnitude of these settlements depends on the thickness of the deformable soil, the deformability of the soft soil and the increase of the effective stresses which depends on the piezometric level fall.

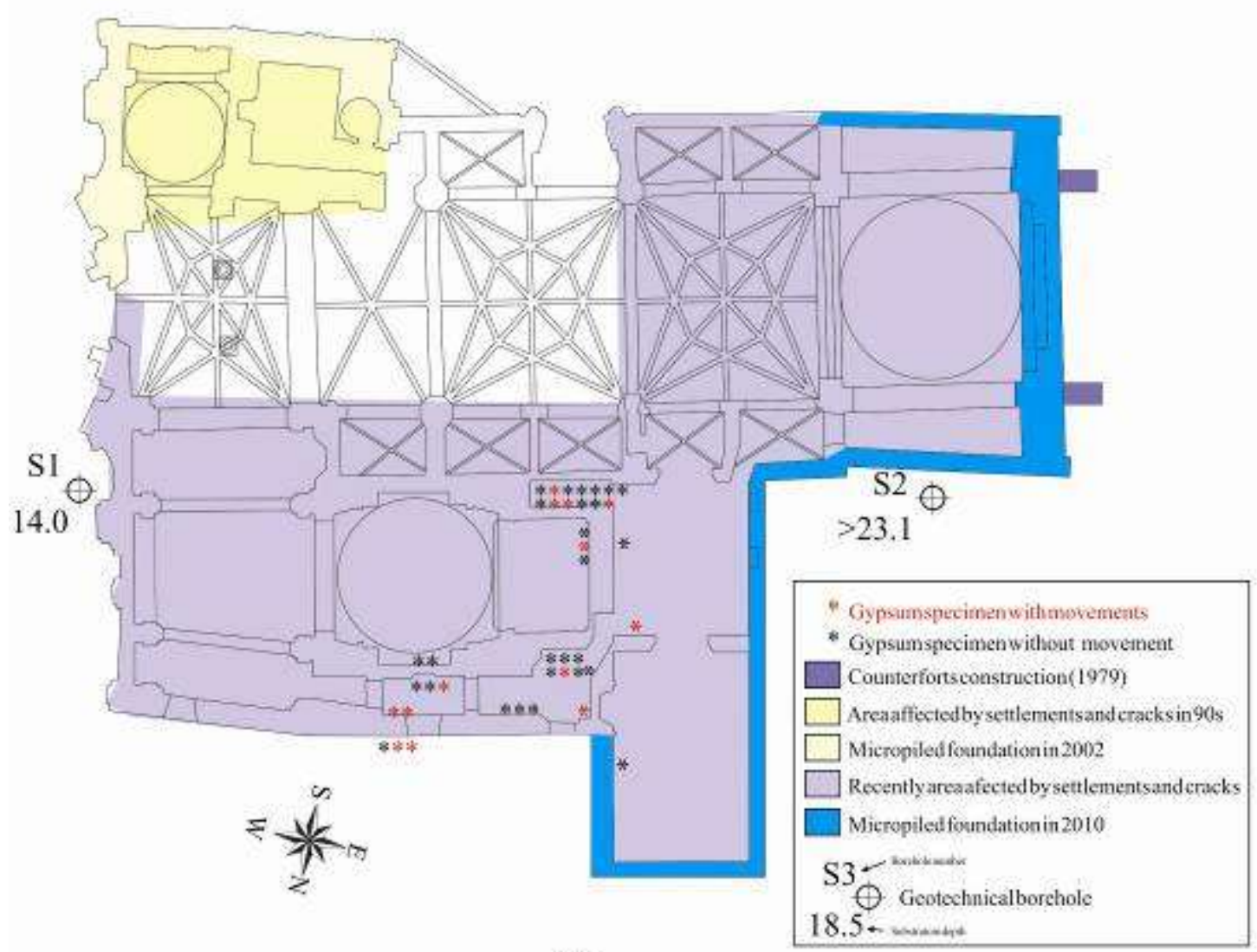

Figure 6. Gypsum plaster markers, geotechnical boreholes location and structural improvement actions performed on the church. Notice that the plaster markers control period was November 2006-June 2008. See geotechnical boreholes lithological description on Figure 4.

213 The eastern wall that closes the principal chapel suffered an important tilt in 70 s decade. The 214 problem was solved by means of the construction of two reinforced concrete counterforts 215 (Figures $5 \mathrm{~b}$ a 6 ). After that, deformations affecting the church have occurred in two different 216 phases. In the ninety decade of the last century, important settlements affected the San José 217 chapel zone (Southwest area of the church, Figure 6). Unfortunately no in situ observations are 
This paper has to be cited as: Tomás, R., García-Barba, J., Cano, M., Sanabria, M.P., Ivorra, S., Duro, J. \& Herrera, G. 2012. Subsidence damage assessment of a gothic church using Differential Interferometry and field data. Structural Health Monitoring, 11, 751-762. The final publication is available at SAGE journals via: http://shm.sagepub.com/content/11/6/751.abstract

available for this period. As a consequence, the foundation was reinforced in 2002 with micropiles. On a second stage (first decade of present century), deformations affected the whole north zone of the church and the principal chapel area. Ground settlements were visible at the floor of the antesacristy, the sacristy and La Comunión chapel. Multiple cracks where identified in the north, west and east walls, affecting as well La Comunión cupola (Figures 5b, c and e), the sacristy and the antesacristy. Several plaster markers were placed in the cracks in 2006 and controlled in 2008 coinciding with the higher piezometric level fall never known in the Vega Baja of the Segura River basin (Figure 7). Figure 6 shows that multiple cracks grew up for this period as a consequence of the sinking of the walls foundation caused by ground subsidence. This affected zone of the church has been recently repaired in 2010 using micropiles (Figure 6).
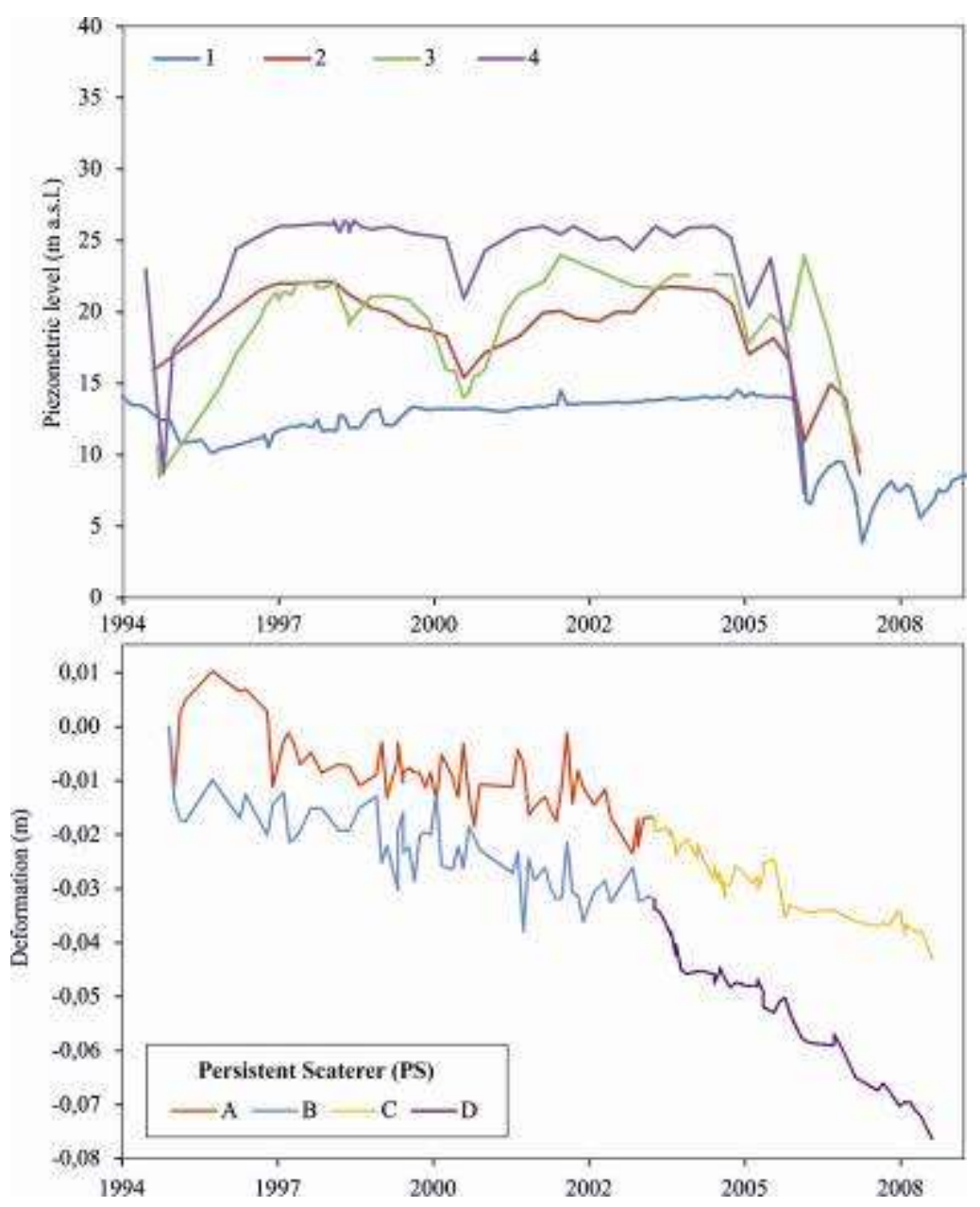

Figure 7. Piezometric level evolution of several piezometers located in the Vega Baja of the

233 Segura river superposed to DInSAR deformation time series of 2 PSs located in the vicinity of the Santas Justa and Rufina church (see A, B, C and D PSs location in Figure 9 and 1, 2, 3 and 
This paper has to be cited as: Tomás, R., García-Barba, J., Cano, M., Sanabria, M.P., Ivorra, S., Duro, J. \& Herrera, G. 2012. Subsidence damage assessment of a gothic church using Differential Interferometry and field data. Structural Health Monitoring, 11, 751-762. The final publication is available at SAGE journals via: http://shm.sagepub.com/content/11/6/751.abstract

4 piezometers location in Figure 3). Notice that PS time series of both DInSAR processed periods has been jointed for neighborhood PSs in order to have complete temporal series for 1995-2008.

\section{DInSAR survey}

240 The forensic analysis of the Santas Justa and Rufina church has been supported by DInSAR data. Specifically, in this work ground subsidence measurements have been obtained using a

242 Persistent Scatterer Interferometry (PSI) technique called Stable Point Network (SPN). A in 243 depth description of this technique can be found in Arnaud et al. (2003) and Duro et al. (2005) 244 but a summary is included here for the sake of completeness.

245 The SPN algorithm uses the DIAPASON (Differential Interferometric Automated Process 246 Applied to Survey Of Nature) interferometric software for all SAR data handling, e.g. co247 registration work and interferograms generation. The SPN method generates three main 248 products from a set of Single Look Complex (SLC) SAR images (Duro et al., 2005): (a) the 249 displacement rate (average deformation velocity) measured along line of sight (LOS) of single 250 Persistent Scatterer (PS); (b) a map of height error; and (c) the LOS displacement time series of 251 individual PS (as a function of time).

252129 images acquired by the European Space Agency (ESA) ERS-1/2 and Envisat ASAR 253 sensors covering two periods July 1995-December 2005 and January 2004-December 2008 254 have been used in this work for the deformation study. From all the pairs of images 255 combinations, only interferometric pairs with a perpendicular spatial baseline smaller than 800 $256 \mathrm{~m}$ and a temporal baseline shorter than 6 and 3 years for 1995-2005 and 2004-2008 periods 257 respectively, and a relative Doppler centroid difference below $400 \mathrm{~Hz}$ have been selected.

258 The DEM used Digital Elevation Model used for processing has been Shuttle Radar 259 Topography Mission (SRTM) ones. The pixel selection for the estimation of displacements was 260 based on a combination of several quality parameters including low amplitude standard 261 deviation and high model coherence. Coherence is an indicator of the degree of correlation 262 between two SAR images. So, this parameter is used as a measure of the quality of an 263 interferogram. Coherence values near 1 indicate a good correlation although 0 indicates no 264 correlation.

265 Results of subsidence in the city of Orihuela for both periods (1995-2005 and 2004-2008) are 266 shown in Figure 8. As it can be seen in figure $8 a$ and $b$, the higher density of PSs corresponds 267 to the urban area of Orihuela. In the Santas Justa y Rufina church neighborhood deformation 268 rates up to -2.1 and $-9.5 \mathrm{~mm} /$ year for 1995-2005 and 2004-2008 periods respectively have been 269 measured by means of DInSAR (Figure $8 a$ to $8 d$ ). Notice that subsidence measured for 20042702008 period in the vicinity of the church is higher than the measured deformation for the 
This paper has to be cited as: Tomás, R., García-Barba, J., Cano, M., Sanabria, M.P., Ivorra, S., Duro, J. \& Herrera, G. 2012. Subsidence damage assessment of a gothic church using Differential Interferometry and field data. Structural Health Monitoring, 11, 751-762. The final publication is available at SAGE journals via: http://shm.sagepub.com/content/11/6/751.abstract

271 previous period (1995-2005) due to the previously mentioned high piezometric level drop that 272 affected the area because of the aquifer overexploitation. Unfortunately, no PSs are available 273 for both periods for Santas Justa and Rufina church. This is due to the loss of coherence, which 274 is associated to the reforms performed in the cover and façades of the church in 1998 and 275 2002, just during the period comprised by processing. However, several PSs are available for 276 the nearby areas of the church.

277 Figure $8 \mathrm{~g}$ represents $\mathrm{N}$-S cross section of the study area. As it can be noticed, Holocene 278 sediments from the flood plain of the Segura River increase their thickness from the north 279 towards south (from the Sierra de Orihuela relief towards the center of the basin). Subsidence 280 follows a similar trend. The Santas Justa and Rufina church is just located near the Sierra de 281 Orihuela that is composed of carbonatic rocks (dolostones and limestones). This relief deepens 282 under Holocene sediments with high slopes causing important changes in substratum depth as 283 it has been observed in the available boreholes performed in the church perimeter (Figure 4).

284 These substratum changes favor differential settlements occurrence. Differential settlements 285 affecting the church have been computed interpolating the available data for both study periods 286 (Figure 9). The maximum differential settlements have been calculated considering the highest 287 and the lowest subsidence values contained in an area composed by the church and a buffer 288 ring of $14 \mathrm{~m}$ providing 12.5 and $24.46 \mathrm{~mm}$ for 95-06 and 04-08 periods respectively. The 289 angular distortion has been obtained dividing differential settlement by the distance between the 290 two points that provides the maximum and minimum subsidence value. Computed distortion 291 values for both periods are $1.5 \times 10^{-4} \mathrm{~m} / \mathrm{m}$ and $3.4 \times 10^{-4} \mathrm{~m} / \mathrm{m}$. 
This paper has to be cited as: Tomás, R., García-Barba, J., Cano, M., Sanabria, M.P., Ivorra, S., Duro, J. \& Herrera, G. 2012. Subsidence damage assessment of a gothic church using Differential Interferometry and field data. Structural Health Monitoring, 11, 751-762. The final publication is available at SAGE journals via: http://shm.sagepub.com/content/11/6/751.abstract
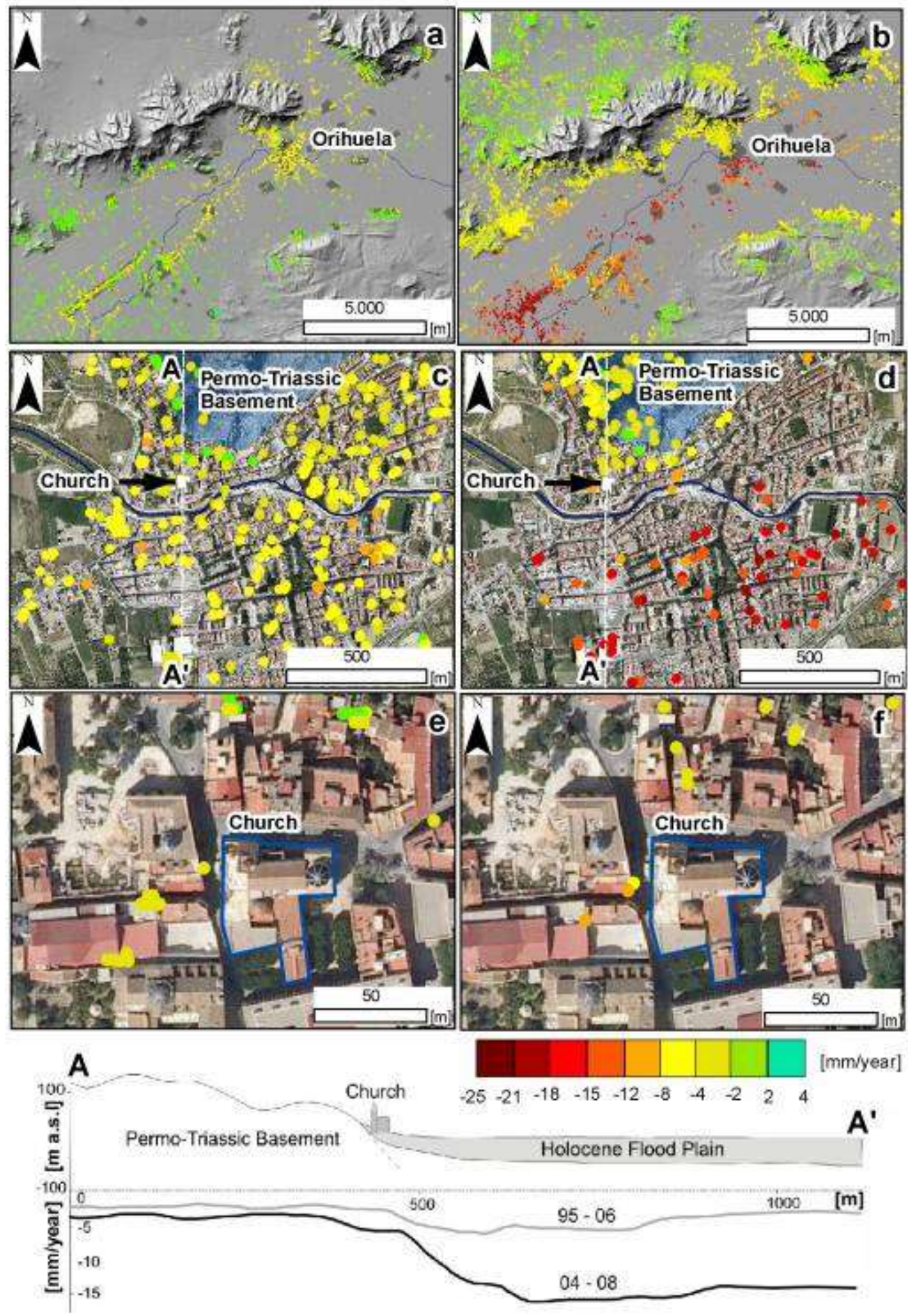

294 Figure 8. Subsidence measured by means of DInSAR for 1995-2005 and 2004-2008 periods:

295 a) and b) for the whole study area; c) and d) in Orihuela city; e) and f) in the vicinity of the 296 church; g) Geological simplified and subsidence N-S cross section along Orihuela city. 
This paper has to be cited as: Tomás, R., García-Barba, J., Cano, M., Sanabria, M.P., Ivorra, S., Duro, J. \& Herrera, G. 2012. Subsidence damage assessment of a gothic church using Differential Interferometry and field data. Structural Health Monitoring, 11, 751-762. The final publication is available at SAGE journals via: http://shm.sagepub.com/content/11/6/751.abstract

\section{Diagnosis}

300 In this section the causes of observed structural pathologies are analysed. Although other 301 pathologies previously described (alveolization, humidity, etc.) affect the Santas Justa and 302 Rufina church, this work is focused on the pathologies caused by ground subsidence.

303 From a geotechnical point of view, the church is founded over deformable Holocene clays and 304 silts with an intercalated sandy silt layer. All of them present a low bearing capacity with very low values of standard penetration (lower than 15 blow counts). Geotechnical substratum, composed by dolostones and limestones with a high bearing capacity, is placed beneath the previously described layer. The geotechnical substratum depth varies from $-14 \mathrm{~m}$ in borehole

$308 \mathrm{~S} 1$ to more than $-23.1 \mathrm{~m}$ in borehole 2. This means that an important spatial variation of 309 deformable soil thickness is expected in the church subsoil that favours the occurrence of 310 differential settlements of the structure.

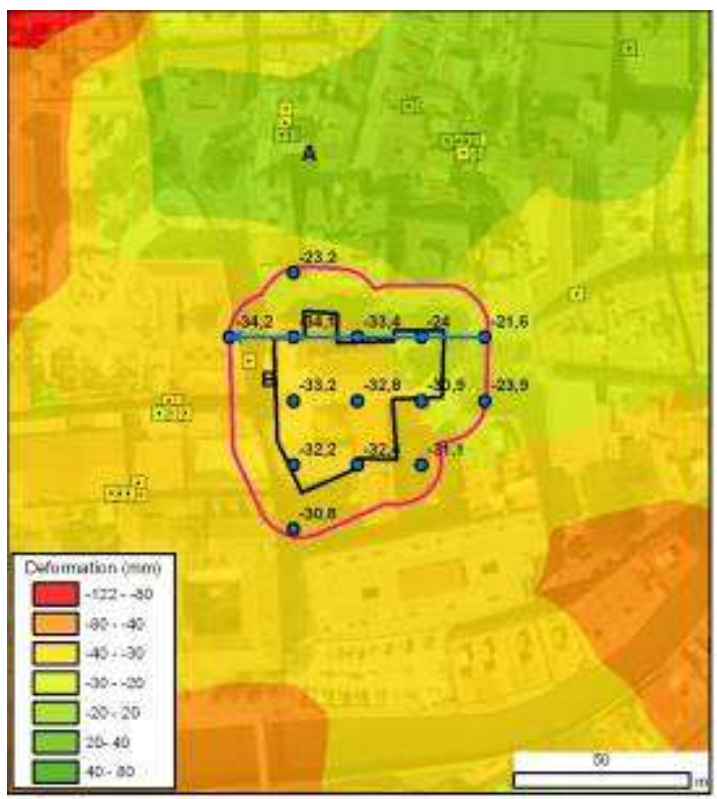

Angular distortion vector

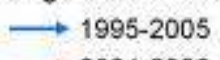

$\longrightarrow 2004-2008$

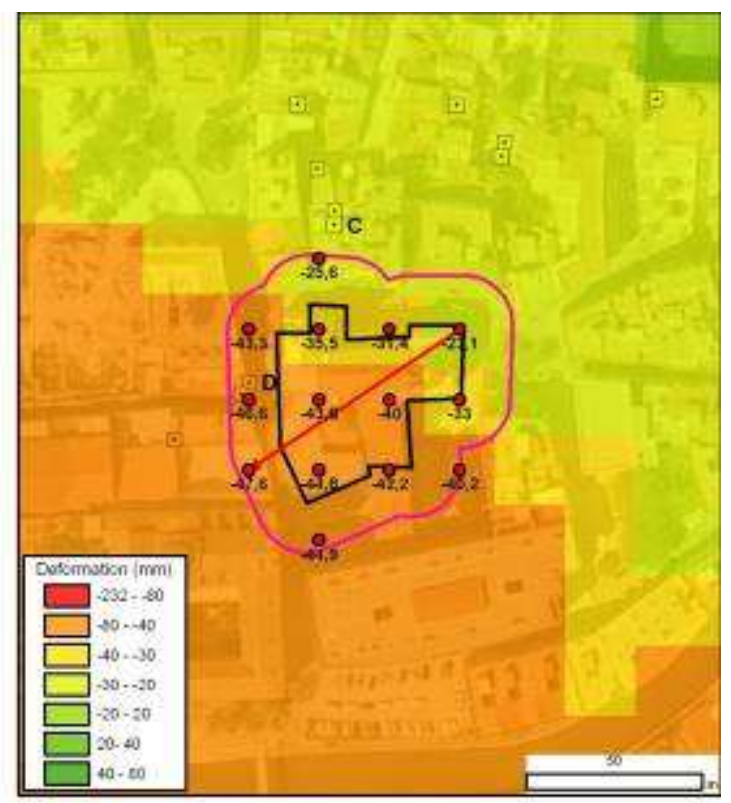

SPs (A, B, C, D)

Buffer (14 m)

313 Figure 9. Interpolated DInSAR subsidence in the vicinity of the Santas Justa and Rufina church

314 and computation of differential settlements and maximum deformation gradients for 1995-2006

315 and 2004-08 periods. Notice that the arrow indicates the direction of maximum deformation 316 gradient.

318 DInSAR results (Figure 8) show that the whole Orihuela city has suffered subsidence due to 319 water withdrawal at least since 1995 with sinking values up to $100 \mathrm{~mm}$. This subsidence has 
This paper has to be cited as: Tomás, R., García-Barba, J., Cano, M., Sanabria, M.P., Ivorra, S., Duro, J. \& Herrera, G. 2012. Subsidence damage assessment of a gothic church using Differential Interferometry and field data. Structural Health Monitoring, 11, 751-762. The final publication is available at SAGE journals via: http://shm.sagepub.com/content/11/6/751.abstract

320 been proved to be closely related with piezometric level changes (Figure 7) suffering an 321 important acceleration when the piezometric level dropped drastically from 2004 to 2008. 322 Although no PSs are available for the Santas Justa and Rufina church due to the loss of 323 coherence derived from the maintenance works performed in its cover, subsidence rate values 324 up to -21 and $-95 \mathrm{~mm}$ per year have been measured for 1995-2006 and 2004-2008 periods, 325 respectively, in the nearby areas of the church (Figures 7 and 9). Computed differential 326 settlements using interpolated maps provide maximum differential settlements affecting the 327 church of 12.5 and $24.5 \mathrm{~mm}$ for $1995-2006$ and 2004-2008 periods, respectively. As it can be 328 notice, these values are lower than the general rule of $25.4 \mathrm{~mm}$ (equals to 1"; Terzaghi et al., 329 1996) of acceptable maximum differential settlement, although during the second period 330 deformations are very close to it. Computed angular distortions reached values of $1.5 \times 10^{-4}$ $331 \mathrm{~m} / \mathrm{m}$ and $3.4 \times 10^{-4} \mathrm{~m} / \mathrm{m}$ that are also lower than the ones generally accepted of $(1 / 1000$ $332 \mathrm{~m} / \mathrm{m}$ ). However, the 1995-2008 differential settlement probably got over this value.

333 The interpolated subsidence values of subsidence also allow interpreting the deformational 334 evolution of the church. As it was explained in section 5 , in the ninety decade, high settlements 335 affected the San José chapel zone. Figure 9a shows that the maximum settlements for 19953362006 period were concentrated on the NW corner of the church, just coinciding with the 337 mentioned area. Also notice that the computed angular distortion (blue arrow) is oriented from E

338 towards $\mathrm{W}$ coinciding with the San José chapel zone. The foundation was repaired in 2002 339 using micropiles. More recent damages are concentrated in the SE zones (La Comunión 340 chapel, antesacristy and sacristy; Figures 6). As it was explained in section 5 field work has 341 been performed in order to identify the damages affecting this area. Observed damages consist 342 principally on floor settlements (pavement irregularities are easily recognized) and wall cracks 343 that can affect other elements. Figure $9 \mathrm{~b}$ shows that maximum interpolated settlements for the 344 2004-2008 period are concentrated on the SW corner of the church with a maximum angular 345 distortion direction NE-SW (the church has undergone a tilt towards the SW) in agreement with 346 field observations.

\section{Conclusions}

349 The gothic church of Santas Justa and Rufina, located in Orihuela (SE, Spain) has suffered several damages due to regional subsidence processes, scarcely related with piezometric level oscillations. The church subsoil is favourable for subsidence occurrence. It is composed of fillings and Holocene fine materials (silts and clays) with some coarse intercalations (silty sand) that reach thickness higher than $23.1 \mathrm{~m}$ at the $\mathrm{E}$ of the church. Field works have allowed to identify the more affected zones of the church providing detailed data about the kinds of pathologies affecting the church. Moreover, DInSAR data have permitted to perform a global interpretation of the deformations affecting the church. Although, no PS are available for the church due to the loss of interferometric coherence caused by the maintenance works 
This paper has to be cited as: Tomás, R., García-Barba, J., Cano, M., Sanabria, M.P., Ivorra, S., Duro, J. \& Herrera, G. 2012. Subsidence damage assessment of a gothic church using Differential Interferometry and field data. Structural Health Monitoring, 11, 751-762. The final publication is available at SAGE journals via: http://shm.sagepub.com/content/11/6/751.abstract

358 performed in the church cover, settlement values up to $-9.5 \mathrm{~mm} /$ year for 2004-2008 have been 359 measured by means of DInSAR in the vicinity of the church. Furthermore, the analysis of the 360 interpolated DInSAR data has allowed estimating differential settlements of $24.5 \mathrm{~mm}$ and

361 angular distortions of $3.4 \times 10^{-4} \mathrm{~m} / \mathrm{m}$ for the $2004-2008$ periods affecting the church. Although 362 the computed values of differential settlements for both independent periods are lower than 363 allowable settlement ( $<25.4 \mathrm{~mm}$ equals to 1 ") probably, the values corresponding to the whole 364 subsidence temporal period (1995-2008) exceed this tolerable settlement. These data are 365 consistent with in situ data and field observations proving that DInSAR is a powerful tool that 366 can be very useful for performing buildings forensic analysis jointly with in situ data.

\section{Acknowledgements}

369 Authors José Luis Satorre (Priest of Santa Justa and Rufina church), Excelentísimo 370 Ayuntamiento de Orihuela and Jenaro Vera (University of Alicante) by the provided information 371 and/or their useful comments. The European Space Agency (ESA) Terrafirma project has 372 funded all the SAR data processing with the SPN technique. Additionally, this work has been 373 partially financed by supported by the projects: TEC-2008-06764, ACOMP/2010/082, VIGROB374 157, 15224/PI/10 and BEST-2011/225.

References

377 Batuhan Osmanoğlu, Timothy H. Dixon, Shimon Wdowinski, Enrique Cabral-Cano and Yan 378 Jiang (2010). Mexico City subsidence observed with persistent scatterer InSAR. International 379 Journal of Applied Earth Observation and Geoinformation 13, 1-12

380 Bénédicte Fruneau, Benoît Deffontaines, Jean-Paul Rudant, Anne-Marie Le Parmentier (2005). 381 Monitoring vertical deformation due to water pumping in the city of Paris (France) with 382 differential interferometry Original Research Article Comptes Rendus Geosciences, Volume 383 337, Issue 13, September-October 2005, Pages 1173-1183

384 Bru, G., Herrera, G., Tomás, R., Duro, J., De la Vega, R., Mulas, J. Control of deformation of 385 buildings affected by subsidence using persistent scatterer interferometry. Structure and 386 infrastructure engineering. Accepted in press, DOI: 10.1080/15732479.2010.519710, 2010.

387 Chabas, A., Jeannette, D. (2001). Weathering of marbles and granites in marine environment: 388 petrophysical properties and special role of atmospheric salts Environmental Geology 40, 359389368.

390 De Larouziére, F.D., Bolze, J., Bordet, P., Hernández, J., Montenat, C., Ott D'Estevou, P. 391 (1988). The Betic segment of the lithospheric trans-Alboran shear zone during the Late 392 Miocene. Tectonophysics 152, 41-52. 
This paper has to be cited as: Tomás, R., García-Barba, J., Cano, M., Sanabria, M.P., Ivorra, S., Duro, J. \& Herrera, G. 2012. Subsidence damage assessment of a gothic church using Differential Interferometry and field data. Structural Health Monitoring, 11, 751-762. The final publication is available at SAGE journals via: http://shm.sagepub.com/content/11/6/751.abstract

393 Delgado J, Alfaro P, Andréu JM, Cuenca A, Doménech C, Estévez A, Soria JM, Tomás R, 394 Yébenes A. (2003). Engineering-geological model of the Segura river flood plain (SE Spain): a 395 case study for engineering planning. Eng. Geol., 68, 171-187.

396 Herrera, G., Tomas, R., Monells, D., Centolanza, G., Mallorqui, J.J., Vicente, F., Navarro, V.D., 397 Lopez-Sanchez, J.M, Cano, M., Mulas, J., Sanabria, M. (2010). Analysis of subsidence using 398 TerraSAR-X data: Murcia case study. Engineering Geology, 116, 284-295, 2010

399 Ivorra, S., F.J. Pallarés, J.M. Adams, R. Tomás. An evaluation of the incidence of soil 400 subsidence on the dynamic behaviour of a Gothic bell tower. Engineering Structures. 32, 8, $401 \quad 2318-2325,2010$.

402 Sandra I.N. Heleno, Luís G.S. Oliveira, Maria J. Henriques, Ana P. Falcão, José N.P. Lima, 403 Geraint Cooksley, Alessandro Ferretti, Ana M. Fonseca, João P. Lobo-Ferreira, João F.B.D. 404 Fonseca (2011). Persistent Scatterers Interferometry detects and measures ground subsidence 405 in Lisbon. Remote Sensing of Environment, Volume 115, Issue 8, 15 August 2011, Pages 21524062167.

407 Sanz de Galdeano, C. (1990). Geologic evolution of the Betic Cordilleras in Western 408 Mediterranean, Mio-cene to the present. Tectonophysics 172, 107-119.

409 Stramondo, S., F. Bozzano, F. Marra, U. Wegmuller, F.R. Cinti, M. Moro, M. Saroli (2008).

410 Subsidence induced by urbanisation in the city of Rome detected by advanced InSAR technique 411 and geotechnical investigations. Remote Sensing of Environment, Volume 112, Issue 6, 16 412 June 2008, Pages 3160-3172

413 Terzaghi, K., Peck, R.B., Mesri, G. (1996). Soil mechanics in engineering practice. $3^{\text {rd }}$ edition. 414 John Wiley \& Sons, 592 pp.

415 Tomás, R., Herrera, G., Lopez-Sanchez, J.M., Vicente, F., Cuenca, A. \& Mallorquí, J.J. (2010). 416 Study of the land subsidence in the Orihuela city (SE Spain) using PSI data: distribution, 417 evolution and correlation with conditioning and triggering factors. Engineering Geology, 115, $418 \quad 105-121$.

419 Tomás, R., Lopez-Sanchez, J.M., Delgado, J., Mallorquí, J.J. \& Herrera, G. (2008). DInSAR 420 monitoring of aquifer compaction due to water withdrawal: Vega Baja and Media of the Segura 421 river (SE, Spain) case study. In J.M. Sánchez (Ed.), Drought: causes, effects and predictions 422 (pp. 253-276). New York: NOVA Publishers.

423 Tomás, R., Lopez-Sanchez, J.M., Delgado, J., Vicente, F., Cuenca, A., Mallorquí, J.J., Blanco, 424 P. \& Duque S. (2007). DInSAR monitoring of land subsidence in Orihuela city, Spain: 425 comparison with geotechnical data. IEEE Int. Geosci. Remote Sens. Symp., IGARSS 2007, 426 Barcelona, 23-28 Julio, 3027-3030. 